Матеріали Всеукраїнської науково-практичної конференчії «Актуальні питання діагностики, лікування, раціональної фармакотерапії, диспансеризації та реабілітації в практичі сімейного лікаря"

DOI

\title{
ДІАГНОСТИКА ЕНДОТЕЛІАЛЬНОЇ ДИСФУНКЦІї У ХВОРИХ НА АУТОІМУННИЙ ТИРЕОЇДИТ ЗА НАЯВНОСТІ АТЕРОСКЛЕРОТИЧНОГО УРАЖЕННЯ СУДИН
}

๑Н. І. Чекаліна, Ю. М. Казаков, Т. В. Мамонтова, Ю. Г. Бурмак, 3. О. Борисова

Вищий державний навчальний заклад України «Українська медична стоматологічна академія»

Вступ. Поширеність аутоімунного тиреоїдиту (AIT) в Україні за останні 10 років зросла на $68 \%$. AIT $\epsilon$ найчастішою причиною гіпотиреозу (7080 \% випадків). Ендотеліальна дисфункція (ЕД), що формується в умовах запального процесу, на сьогодні розцінюється як основний патогенетичний чинник формування атеросклеротичного ураження судин, яке $\epsilon$ морфологічною основою ішемічної хвороби серця (IXC). Тому пошук показових маркерів ЕД як при AIT, так і при атеросклерозі (AC), $\epsilon$ актуальним для оптимізації діагностики, оцінки перебігу та ефективності лікувальних заходів.

Мета - дослідити показники ЕД у хворих на AIT у поєднанні з IXC та атеросклеротичним ураженням сонних артерій.

Матеріали і методи. До дослідження залучено 75 осіб обох статей віком від 48 до 72 років: 55 хворих з наявністю ознак АС (потовщення комплексу «інтима-медіа» (КIM) загальних сонних артерій більше 0,9 мм, атеросклеротичні бляшки) та доведеної за допомогою тесту з дозованим фізичним навантаженням (велоергометрія) IXC (стенокардія напруги стабільна, І-ІІ ФК), що склали групу порівняння, та 20 осіб, які додатково мали діагноз AIT (5 - субклінічний гіпотиреоз із призначенням відповідних доз L-тироксину (25-75 мкг на добу), решта - еутиреоїдний варіант перебігу AIT), що увійшли до групи дослідження. 15 добровольців склали групу здорових осіб. Усім учасникам дослідження у крові визначено кількість циркулюючих ендотеліальних мікрочастинок (ЦЕМ) цитофлуориметричним методом шляхом виявлення специфічних поверхневих мембранних молекул за допомогою моноклональних антитіл проти антигенів CD32 та CD40. У якості додаткового маркера, що обумовлює пошкодження ендотелію, визначали рівень у крові фактора некрозу пухлини а (TNF-a) шляхом імуноферментного аналізу.

Результати. У хворих групи дослідження (AIT у поєднанні з IXC) вміст ЦЕМ CD32+ CD40+ у периферійній крові був вірогідно вищим за показники хворих групи порівняння (IXC) $2,62(1,50-6,10) \times 10^{7} / л$ проти 1,8 $(1,12-4,96) \times 10^{7} / л$ $(U, p=0,036)$. Це свідчить про високий рівень ЕД при хронічному аутоімунному запаленні. У здорових осіб кількість ЦЕМ відповідала 1,3 $(0,69-2,47) \times 10^{7} / л$. При поєднанні IXC та AІT рівень TNF-a був вірогідно вищим, ніж в групі порівняння $(10,54 \pm 2,42$ пг/мл проти 8,53 23,24 пг/мл). У здорових осі6 TNF-а складає 0-6 пг/мл. За отриманими даними, наявності ЕД відповідає значення показника ЦЕМ > 2,5×107/л та > 7,9 пг/мл. Визначено тісний кореляційний зв'язок між показниками ЦЕМ та TNF-a $(r=0,81)$. Чутливість (Se) та специфічність (Sp) при використанні зазначеної пари показників для діагностики ЕД у хворих групи дослідження склали $82 \%$ та 83 \% відповідно.

Висновки. При поєднанні АІT з IXC виявлено вірогідно більш виражені ознаки ЕД, ніж у хворих на IXC, що обумовлено впливом імунного запалення. Визначення кількості ЦЕМ за антигенними маркерами активації ендотеліоцитів $\mathrm{CD} 32^{+} \mathrm{CD} 40^{+}$ у поєднанні з вмістом TNF-a $\epsilon$ інформативним високочутливим методом верифікації ЕД у хворих на AIT за наявності атеросклеротичного ураження судин. 